\title{
PENGOLAHAN JAHE PANDAN MENJADI PRODUK MINUMAN HERBAL (JAPAN) UNTUK MENINGKATKAN KUALITAS SDM EKONOMI KREATIF DI DESA KAMPAK KECAMATAN GEGER
}

\author{
Imam Haromin, Bahrul Ulum, Abdul Aziz \\ STAI Darul Hikmah Bangkalan \\ haromain234@gmail.com, bahrululum@darul-hikmah.com, \\ abd.aziz@darul-hikmah.com
}

\begin{abstract}
ABSTRAK
Entrepreneurship adalah suatu proses dimana seseorang atau suatu kelompok individu menggunakan upaya yang terorganisir \& sarana untuk mencari sebuah peluang dan menciptakan suatu nilai yang tumbuh dengan memenuhi kebutuhan serta keinginan melalui sebuah inovasi dan keunikan, melalui proses mengidentifikasi, mengembangkan dan membawa visi ke dalam kehidupan. Dalam usaha yang akan kami kelola ini merupakan jenis usaha yang bergerak dibidang pengolahan yang bermanfaat bagi kesehatan. Produk minumn herbal jahe pandan (Japan) menggunakan bahan baku yaitu jahe dan daun pandan. Kami menggunakan bahan tersebut karena sangat mudah ditemukan dan harganya sangat terjangkau. Produk minuman herbal yang kami buat, dikemas dalam botol yang sudah disterilkan. Tak hanya nikmat, minuman japan juga kaya akan manfaat untuk kesehatan. Itulah sebabnya, minuman ini masuk dalam daftar minuman yang dapat dipilih oleh siapa saja yang sedang mempratikkan gaya hidup kembali ke alam.
\end{abstract}

Kata Kunci: Jahe Pandan, Ekonomi Kreatif 


\section{A. LATAR BELAKANG}

Entrepreneurship adalah suatu proses dimana seseorang atau suatu kelompok individu menggunakan upaya yang terorganisir \& sarana untuk mencari sebuah peluang dan menciptakan suatu nilai yang tumbuh dengan memenuhi kebutuhan serta keinginan melalui sebuah inovasi dan keunikan, melalui proses mengidentifikasi, mengembangkan dan membawa visi ke dalam kehidupan. Visi tersebut bisa berupa ide inovatif, peluang, cara yang lebih baik dalam menjalankan sesuatu. Hasil akhir dari proses tersebut adalah penciptaan usaha baru yang dibentuk pada kondisi risiko atau ketidakpastian. Orang yang melakukan kegiatan kewirausahaan disebut Wirausaha.

Seorang entrepreneur harus memiliki cara berfikir yang inovatif. Seorang entrepreneur juga harus mampu, pandai dan teliti dalam melihat peluang usaha yang tersedia. Kondisis lingkuangan usaha itu juga mimiliki pengaruh yang besar terhadap kemajuan usaha tersebut. Usaha yang hanya berpredikat sebagai plagiat tidak akan mampu mengembangkan usahanya. Hal ini dikarenakan konsumen akan berfikir jika produk yang disajikan sama saja dengan produk yang sudah beredar dipasaran maka dari itu harus memiliki perbedaan atau keunggulan dibandingkan dengan produk yang telah beredar supaya produk baru tersebut mampu menarik perhatian konsumen.

Entrepreneur juga harus mampu membaca peluang tentang keberadaan suatu produk. Produk yang jarang ditemukan di suatu daerah sedangkan konsumen banyak membutuhkan akan menjadikan produk tersebut laris di pasaran. Salah satu produk yang sudah jarang ditemukan adalah minuman tradisional atau minuman herbal. Kelangkaan usaha yang seperti inilah yang dapat dijadikan bisnis usaha yang menjajikan. 
Akan tetapi, semua itu juga tergantung bagaimana kejelian seoarang entrepreneur melihat peluang yang tersedia.

Entrepreneurship merupakan peluang mengembangkan usaha sesuai kemampuan pribadi masing - masing, namun seorang wirausaha harus mempunyai kecakapan dalam menganalisis SWOT, sehingga dapat mengembangkan usaha dengan baik dan lancar, tidak menimbulkan kegagalan produksi ditengah jalan, maka seorang wirausaha harus merencanakan usaha semaksimal mungkin, agar usaha berkembang dengan cepat.

Dengan berubahnya pola konsumsi masyarakat kepada bahan non sintetis dan ditambah dengan tingginya permintaan masyarakat akan minuman kesehatan dengan bahan-bahan alami yang tidak menimbulkan efek samping yang membahayakan, maka bisnis minuman herbal menemukan momentum yang tepat untuk dikembangkan. Permintaan konsumen terhadap produk - produk minuman kehesahatn tetap tumbuh, hal ini berbeda dengan kondisi bisnis di sektor lain. Bisnis minuman kesehatan adalah salah satu bisnis yang mempunyai daya resistensi tinggi terhadap fluktuasi perekonomian. Dengan kondisi konsumen seperti ini maka menjalankan bisnis minuman kesehatan adalah pilihan yang tepat.

Dalam suatu pemasaran banyak sekali bentuk dan macam-macam minuman herbal, dari harga yang murah sampai harga yang mahal. Dalam kebutuhan sehari-hari banyak sekali aktivitas yang dijalani oleh setiap orang. Dengan aktivitas yang semakin padat, membuat banyak orang membutuhkan minuman yang tentunya bermanfaat bagi kesehatan.

Minuman herbal jahe pandan (JAPAN) merupakan produk herbal asli dari rempah-rempah yang terdiri jahe dau pandan, gula pasir. 
Minuman jahe pandan sangat cocok diminum sehari-hari, bisa disajikan dalam keadaan hangat maupun ditambahkan es batu agar lebih segar untuk minuman kesehatan. Selain itu Air rebusan daun pandan dengan jahe dan serai memiliki manfaat untuk tubuh. Dilansir dari AIA, Selasa (2/4), setidaknya ada tiga khasiat dari minum air daun pandan. Pandan memiliki sifat pencahar, dan daunnya dapat bertindak sebagai pereda nyeri. Misalnya nyeri sendiri atau infeksi. Disamping itu, menambahkan daun pandan ke dalam minuman sehari-hari membantu hati untuk melakukan detoksifikasi. Pandan membantu mengeluarkan racun dan zat tidak sehat dari hati dan tubuh. Karena pandan adalah pencahar ringan yang memudahkan proses ekskresi limbah. Menurut sebuah penelitian di Thailand yang diterbitkan di Majalah Pharmacognosy pada 2015, meminum minuman ekstrak pandan membantu orang menurunkan kadar gula dalam darah. Telah terbukti bahwa glukosa plasma dari orang yang diteliti telah menurun secara signifikan selama periode penelitian.

Dengan khasiat yang begitu banyak dan kenikmatan yang dapat menghangatkan, meyegarkan, dan menyehatkan tubuh serta harga jual yang sangat terjangkau, maka tentunya hal ini akan menarik minat masyarakat untuk membelinya. Dari hal tersebut maka saya ingin mengembangkan dan memasarkan prosuk minuman herbal ini agar masyarakat dapat menikmati khasiatnya bagi kesehatan tubuh dan tidak pernah lupa dengan rempah-rempah asli Indonesia.

Luaran kegiatan kewirausahaan "Pengolahan Jahe Pandan Menjadi Produk Minuman Herbal (Japan) Dengan Tema Meningkatkan Kualitas Sdm Dalam Mengembangkan Ekonomi Kreatif." ini diharapkan dapat meningkatkan nilai tambah dari bahan rempah tersebut menjadi produk olahan inovatif dengan nilai jual yang lebih tinggi. Serta bisa 
menjadi salah satu unit usaha yang dapat dikembangkandan menguntungkan bagi mahasiswa.

\section{B. GAMBARAN UMUM USAHA}

Berbagai macam obat dan minuman herbal telah tersebar diseluruh dunia, salah satunya Indonesia. Berbagai macam khasiat untuk kesehatan yang terkandung disetiap obat dan minuman herbal, kadangkadang tidak berfungsi bahkan bisa mendatangkan penyakit baru yang muncul. Hal ini bisa disebabkan oleh beberapa hal, seperti telah banyaknya produk-produk yang telah menggunakan bahan kimia seperti, bahan pengawet, pewarna termasuk juga obat-obatan dan minukan herbal, dan juga factor higienitas serta kondisi lingkungan produksi. Minuman herbal jahe pandan (Japan) adalah olahan produk yang bisa dijamin kemurnian dan higienitasnya serta ditunjang dengan lingkungan yang sangat mendukung dalam berproduksi.

\section{Sumber Daya dan Bahan Baku}

Dalam usaha yang akan kami kelola ini merupakan jenis usaha yang bergerak dibidang pengolahan yang bermanfaat bagi kesehatan. Produk minumn herbal jahe pandan (Japan) menggunakan bahan baku yaitu jahe dan daun pandan. Kami menggunakan bahan tersebut karena sangat mudah ditemukan dan harganya sangat terjangkau. Produk minuman herbal yang kami buat, dikemas dalam botol yang sudah disterilkan.

\section{Peluang Pasar}

Banyaknya penikmat minuman herbal di Indonesia, membuat kami termotivasi untuk berinovasi dengan membuat produk menyehatkan yaitu jahe pandan (Japan). Minuman yang memiliki banyak khasiat untuk kesehatan dengan rasa yang khas, menggunakan 
$100 \%$ bahan murni alami yang mudah didapat bisa menjadi allternatif pilihan para pecinta minuman herbal. tanpa harus khawatir dengan kandungan perasa yang tinggi karena minuman herbal jahe pandan (Japan) menggunakan gula murni. Produk minuman herbal ini tentu memiliki peluang yang sangat besar dan akan meraih keuntungan bisnis yang baik. Sebab masih jarang minuman herbalyang menggunakan jahe dan pandan sebagai bahan utamanya. Kemasan yang menarik juga akan menjadi salah satu factor pendukung dalam menggaet konsumen dan bersaing dengan produk yang lain dipasaran.

\section{Strategi Pemasaran}

Strategi pemasaran yang akan kami lakukan dalam proses penjualan adalah sebagai berikut:

1. Mengenali pelanggan

Kita harus tau pelanggan yan akan kita hadapi itu siapa apakah anakanak, orang dewasa ataupun lainnya kita harus tau bagaimana cara kita menghadapinya.

2. Melakukan promosi

Yakni dengan cara membuat iklan ataupun brosur yang menarik perhatian, sehingga masyarakat akan dapat mengetahuinya dan mengenalnya.

3. Memilih lokasi strategis

Kita akan mencari dan menggunakan tempat yang sekiranya mudah di jangkau oleh masyarakat luas.

4. Menjalin ikatan baik terhadap konsumen

Bersikap sopan baik dalam melayani konsumen sehingga konsumen akan merasa nyaman.

5. Bagi - Bagi Produk Sample 
Membagikan semple gratis sekaligus berbarengan dengan menawarkan promo yang sedang berjalan agar membuat daya tarik bagi calon konsumen. Jika memang pembeli menyukai rasanya pasti akan langsung tertarik untuk membeli produk kita.

6. Menggunakan Barang Promosi

Selain dengan cara pemasaran diatas, cara dengan menggunakan barang promosi juga bisa dijalankan. Misalnya Beli 3 pes bonus gantungan kunci, beli 2 pcs gratis bolpoin dll.

7. Menggunakan Media Sosial atau Internet Marketing

Kita bisa memanfaatkan media sosial seperti BBM, Instagram, Facebook dll untuk mempromosikan dan memperkenalkan produk usaha kita. Sehingga produk juga akan semakin luas dilihat banyak orang.

\section{METODE PELAKSANAAN}

\section{Persiapan Bahan Baku dan Peralatan}

Pada tahap ini, kami melakukan persiapan bahan baku yang digunakan untuk produksi minuman herbal jahe pandan (JAPAN). Dengan melakukan beberapa tahapan dalam proses kegiatan ini, yaitu:

1. Tahap Perencanaan

Hal yang dilakukan pertama kali pada tahap perencanaan yaitu melihat keadaan pasar sebagai langkah awal untuk melakukan sebuah usaha. Tujuannya untuk mengetahui peluang yang ada dipasar yaitu kondisi pasar, minat konsumen, dan perencanaan usaha yang berkelanjutan.

Tahap kedua dalam perencanaan yaitu melakukan uji kelayakan terhadap usaha yang dibangun. Hal ini bertujuan untuk mengetahui 
apakah usaha tersebut memiliki prospek yang baik di masyarakat serta mampu bertahan dalam jangka waktu yang panjang.

2. Tahap Persiapan

Pada tahap persiapan, hal yang dilakukan yaitu pemilihan serta penyediaan bahan baku dan alat-alat produksi. Hal ini bertujuan untuk mempermudah proses produksi usaha yang dijalankan.

3. Tahap Pengadaan Produk

Untuk mengetahui kualitas dari produk yang dibuat, maka harus dilakukan uji coba pembuatan produk sebelum nantinya dipasarkan. Dengan dilakukannya uji coba sampel makan akan diketahui citarasa produk, pengemasan dan sebagai acuan untuk mengenal selera konsumen serta menjadi tolak ukur produk.

4. Tahap Pelaksanaan Kegiatan

Tahap pelaksanaan kegiatan merupakan kegiatan proses produksi. Pada tahap ini terdiri dari beberapa langkah yaitu persiapan bahan baku, kegiatan pengolahan dan pembuatan produk, pengemasan dan pemasaran.

5. Tahap Pelaporan

Tahap pelaporan merupakan tahap akhir pada pasca produksi. Tahap ini berisikan tentang laporan data dari kegiatan pasca produksi dan tahap produksi. Tahap pelaporan ditujukan untuk mengetahui rangkaian kegiatan dan keuntungan yang diperoleh.

\section{Uji Coba Pembuatan}

Uji coba pembuatan kami lakukan selama satu minggu. Hal ini dilakukan untuk mendapatkan produk yang baik serta dapat diterima oleh konsumen. Proses pembuatan produk kami menggunakan peralatan produksi dan kebutuhan bahan baku dalam pembuatan minuman herbal japan adalah sebagi berikut : 
Tabel 1.

Peralatn dan Bahan Baku

\begin{tabular}{l|l}
\hline \multicolumn{1}{c|}{ Peralatan Produksi } & \multicolumn{1}{c}{ Kebutuhan Bahan Baku } \\
\hline Panci Besar & Jahe \\
\hline Kompor Gas & Daun Pandan \\
\hline Tabung Gas & Gula Pasir \\
\hline Oven & \\
\hline Baskom & \\
\hline Botol & \\
\hline Pisau & \\
\hline Centong Besar & \\
\hline Saringan & \\
\hline
\end{tabular}

\section{Cara Pembuatan Minuman Herbal JAPAN}

1. Pertama cuci semua bahan samapai bersih.

2. Kedua rebus air 1 liter berikut jahe 8 gram (bisa disesuaikan selera kita), dan daun pandan 100 gram sampai mendidih.

3. Selanjutnya masukkan gula pasir 80 gram kedalam rebusan lalu diaduk terus sampai merata.

4. Kemudian setelah proses perebusan selesai didiamkan sampai uap panasnya hilang.

5. Lalu saring minuman samapai betul-betul bersih.

6. Setelah itu minuman siap dikemas ke dalam botol yang sudah disterilkan sesuai takaran menggunakan gelas ukur.

7. Minuman herbal jahe pandan (JAPAN) siap untuk dikonsumsi dan dipasarkan.

8. Pemasaran bisa dilakukan secara online yang dapat mempercepat pengenalan produk ini kepada khalayak masyarakat luas. 
Berikut adalah gambar saat pembuatan pada pelatihan ibu ibu PKK Desa Kampak Kecamatan Geger Kabupaten Bangkalan

Gambar 1.

Pelatihan proses produksi minuman herbal jahe pandan

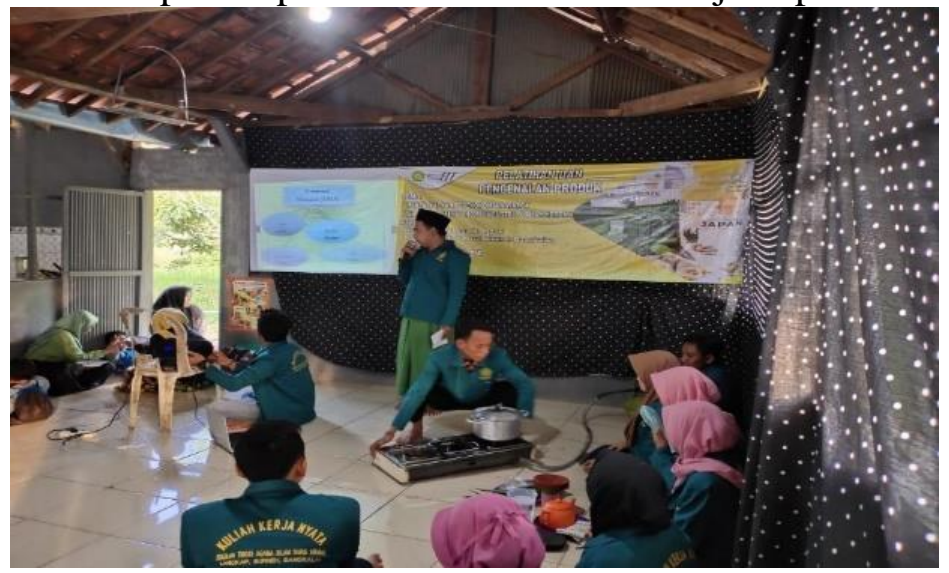

Gambar 2.

Suasana pelatihan proses Produksi minuman herbal jahe pandan (JAPAN).

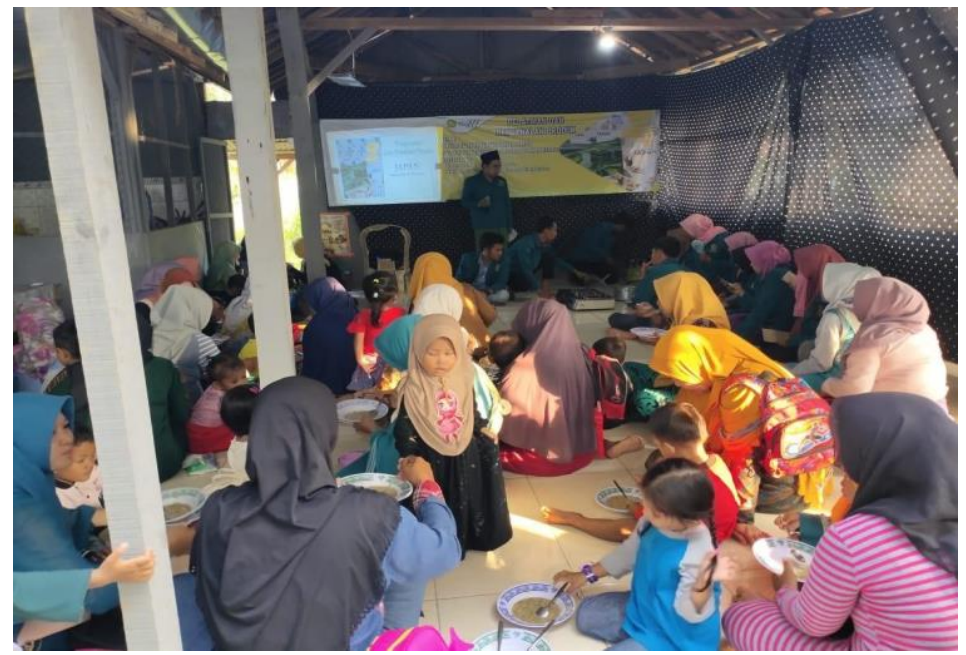

\section{Kelebihan Produk}

Tak hanya nikmat, minuman japan juga kaya akan manfaat untuk kesehatan. Itulah sebabnya, minuman ini masuk dalam daftar minuman yang dapat dipilih oleh siapa saja yang sedang mempratikkan 
gaya hidup kembali ke alam. Adapun beberapa khasiat yang dimiliki jahe dan pandan adalah :

Adapiun khasiat Jahe antara lain adalah Mencegah flu dan sakit tenggorokan, Meredahkan nyeri otot, Mengobati gangguan pencernaan, Mengatasi masuk angin, dll. Sedang khasiat adalah diantaranya Mengatasi rematik, Menurunkan tekanan darah tinggi, Menetralkan racun dalam tubuh.

Berikut hasil produk yang disosilisasikan kepada masyarakat Desa Kampak, yang selanjutnya menjadi salah satu alternatif ekonomi kreatif yang nantinya akan dikembangkan oleh masyarakat Desa Kampak Kecamatam Geger Kabupaten Bangkalan.

\section{Gambar 3.}

Produk minuman herbal jahe pandan (JAPAN)

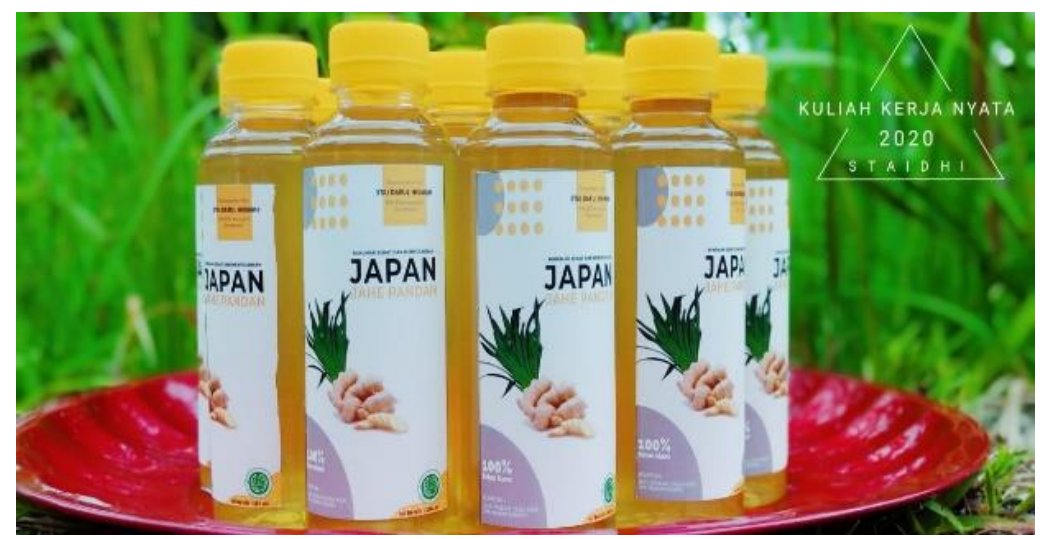




\section{DAFTAR PUSTAKA}

Yuliani, Sri, and Sari Intan Kailaku. "Pengembangan produk jahe kering dalam berbagai jenis industri." (2018).

Effendi, M. Supli. Kajian Organoleptik dan Fisiko Kimia Olahan

Cokelat Rasa Jahe dengan Tempering dan Tanpa Tempering. Diss. Fakultas Teknik Unpas, 2016.

Prastiyo, Agung, Azis Fathoni, and Djamaluddin Malik. "Strategi Pemasaran Produk Jahe Merah Melalui Analisis SWOT Pada

Perusahaan UD. Barokah Ungaran." Journal of Management 4.4 (2018).

Fauzan, Slamet, et al. "Pemberdayaan Masyarakat Desa Seketi Melalui Inovasi Olahan Jahe Merah." Sinergi: Jurnal Pengabdian 2.2 (2020): 65-68.

Retnowati, Nurcahyani Dewi, and Daru Retnowati. "Pengolahan Dan Analisis Usaha Tanaman Jahe Menjadi Produk Jahe Instan Di Panti Asuhan Al-Ikhlas Ngentak Pelem RT. 13 Baturetno Banguntapan Bantul." KACANEGARA Jurnal Pengabdian pada Masyarakat 2.2 (2019): 75-80. 